\title{
Violence against women during covid-19 pandemic restrictions
}

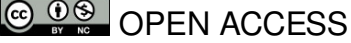 \\ Protections for women and girls must be built into response plans
}

\author{
Elisabeth Roesch consultant ${ }^{1}$, Avni Amin technical officer ${ }^{1}$, Jhumka Gupta associate professor ${ }^{2}$, \\ Claudia García-Moreno acting unit head ${ }^{1}$
}

'Department of Sexual and Reproductive Health, World Health Organization, Geneva, Switzerland; ${ }^{2}$ Department of Global and Community Health, College of Health and Human Services, George Mason University, Fairfax, VA, USA

As the covid-19 pandemic intensifies, its gendered effects have begun to gain attention. Though data are scarce, media coverage and reports from organisations that respond to violence against women reveal an alarming picture of increased reports of intimate partner violence during this outbreak, including partners using physical distancing measures to further isolate affected women from resources. ${ }^{12}$ In Jianli County, Hubei province of China, a police department reported a tripling of domestic violence cases in February 2020 compared with February 2019, estimating that $90 \%$ were related to the covid- 19 epidemic. ${ }^{3}$ In the UK, a project tracking violence against women noted that deaths from domestic abuse between 23 March and 12 April had more than doubled (to 16 deaths) compared with the average rate in the previous 10 years. ${ }^{4}$

These reports are disturbing yet predictable. Globally, $30 \%$ of women experience physical or sexual violence by an intimate partner in their lifetime. ${ }^{5}$ Such violence can increase during humanitarian crises, including conflict and natural disasters. ${ }^{6}$ The gendered impacts of infectious disease epidemics are less understood and acknowledged.

Past epidemics, including Ebola ${ }^{7}$ and $\mathrm{Zika}^{8}{ }^{8}$ suggest violence against women may shift in nature and scale as outbreaks affect social and economic life. ${ }^{9}$ Half of the world's population is being asked to stay at home to slow the spread of covid- $19 .{ }^{10}$ For women already in abusive relationships, or at risk of such abuse, staying at home increases their risk of intimate partner violence. Children may also be exposed to intimate partner violence or be abused themselves. ${ }^{11}$ Urgent steps must be taken to address the risks of violence faced by women and children during pandemic restrictions.

\section{Pathways of risk}

Household stress can increase the likelihood of intimate partner violence. ${ }^{12}$ As people stay at home, families spend more time in close contact, including in cramped conditions.
Simultaneously, the disruption of livelihoods and the ability to earn a living reduces access to basic needs and services, causing additional stress. Perpetrators of partner violence may also restrict access to money or health related items such as hand sanitiser, soap, medications, and access to health services.

The disruption of social and protective networks may further exacerbate intimate partner violence and its consequences. Women may have less contact with family and friends who provide support and protection from violence by a partner. Perpetrators may further restrict access to services, help, and psychosocial support from formal and informal networks.

As health and other support services, including sexual and reproductive health services, are scaled back, women subjected to violence may have less opportunity for receiving support and referrals from the health sector. Other essential support services such as hotlines, crisis centres, shelters, legal aid, and protection and counselling services may also be scaled back, further reducing access to help for women in abusive relationships.

\section{How to respond}

Although the health system is under enormous burden as covid-19 stretches the capacity of hospitals and clinics, the health sector can take steps to mitigate the risk of violence against women during the pandemic restrictions and help reduce its effects (box 1). Governments must include essential services to deal with violence against women in covid-19 response plans, resource them, and identify strategies to make them accessible during physical distancing measures. Health facilities should identify locally available support services for survivors (such as hotlines, shelters, rape crisis centres, counselling) and refer women when they seek health services. 


\section{Box 1: Resources on violence against women}

- Covid-19 and violence against women: What the health sector/system can do (https://www.who.int/reproductivehealth/publications/vaw-covid19/en/)

- Violence against women during covid-19: Q\&A (https://www.who.int/ news-room/q-a-detail/violence-against-women-during-covid-19)

- Health care for women subjected to intimate partner violence or sexual violence: a clinical handbook (https://www.who.int/reproductivehealth/ publications/violence/vaw-clinical-handbook/en/)

- Strengthening health systems for women subjected to intimate partner violence or sexual violence: a health manager's manual (https://www. who.int/reproductivehealth/publications/violence/vaw-health-systemsmanual/en/)

- Caring for women subjected to violence: a WHO curriculum for training health-care providers (https://www.who.int/reproductivehealth/ publications/caring-for-women-subject-to-violence/en/)

- Clinical management of rape and intimate partner violence survivors: developing protocols for use in humanitarian settings (https://www.who. int/reproductivehealth/publications/rape-survivors-humanitarian-settings/ en/)

Health providers should be aware of the risks and consequences of violence against women and provide those affected with support and relevant medical treatment. ${ }^{13}$ It is important to ensure the maintenance of essential medical services, such as for post-rape care, including availability of the necessary medicines and other supplies. Older women, women with disabilities, women living in humanitarian crises contexts, poor women living in crowded conditions, and ethnic minorities may be disproportionately affected and have additional needs. The use of mobile health and telemedicine to safely support those experiencing violence against women must be explored urgently, as well as other means to reach women in settings where access to mobile phones or the internet is limited or lacking. ${ }^{14}$

Importantly, the world's most vulnerable populations will be affected as this pandemic reaches countries with high levels of poverty, displacement, and conflict. Humanitarian organisations need to make services available for women experiencing violence and collect data on reported cases.

We must learn lessons from past epidemics about the failures to recognise and address gender related effects of outbreaks. As the global health community grapples with how best to halt the spread of covid-19, the ongoing epidemic of violence against women cannot be ignored.

Competing interests:We have read and understood BMJ policy on declaration of interests and have no interests to declare. The authors are employed by WHO. The views are those of the authors and do not represent WHO policy.

Provenance and peer review: Not commissioned; externally peer reviewed.

1 Gupta A, Stahl A. For abused women, a pandemic lockdown holds dangers of its own. New York Times 2020 Mar 24. https://www.nytimes.com/2020/03/24/us/coronaviruslockdown-domestic-violence.html

2 Graham-Harrison E, Giuffrida A, Smith H, Ford L. Lockdowns around the world bring rise in domestic violence. Guardian 2020 Mar 28. https://www.theguardian.com/society/2020/ mar/28/lockdowns-world-rise-domestic-violence

3 Allen-Ebrahimian B. China's domestic violence epidemic. Axios 2020 Mar 7. https://www. axios.com/china-domestic-violence-coronavirus-quarantine-7b00c3ba-35bc-4d16-afddb76ecfb28882.html

4 Grierson J. Domestic abuse killings 'more than double' amid covid-19 lockdown. Guardian. $2020 \mathrm{Apr}$ 15. https://www.theguardian.com/society/2020/apr/15/domestic-abuse-killingsmore-than-double-amid-covid-19-lockdown

5 WHO. Global and regional estimates of violence against women: prevalence and health effects of intimate partner violence and non-partner sexual violence. World Health Organization, 2013.

6 Parkinson D, Zara C. The hidden disaster: domestic violence in the aftermath of natural disaster. Aust J Emerg Manag 2013;28:28-35.

7 UNDP. Ebola recovery in Sierra Leone: tackling the rise in sexual and gender-based violence and teenage pregnancy during the ebola crisis. UNDP, 2015.

8 Oxfam International. Dominican Republic gender analysis: study of the impact of the Zika virus on women, girls, boys and men. Oxfam International, 2017.

9 Erika F. Impact of covid-19 pandemic on violence against women and girls, VAWG Helpdesk Research Report No 284. VAWG Helpdesk, 2020.

10 Sandford A. Coronavirus: half of humanity now on lockdown as 90 countries call for confinement. Associated Press, 3 Apr 2020

11 Guedes A, Bott S, Garcia-Moreno C, Colombini M. Bridging the gaps: a global review of intersections of violence against women and violence against children. Glob Health Action 2016:9:31516. 10.3402/gha.v9.31516 27329936

12 Buller AM, Peterman A, Ranganathan M, Bleile A, Hidrobo M, Heise L. A mixed-method review of cash transfers and intimate partner violence in low- and middle-income countries. World Bank Res Obs 2018;33:218-58.10.1093/wbro/lky002.

13 WHO. Health care for women subjected to intimate partner violence or sexual violence: a clinical handbook. https://www.who.int/reproductivehealth/publications/violence/vawclinical-handbook/en/

14 Erskine D. Not just hotlines and mobile phones: gender-based violence service provision during covid-19. Unicef, 2020.

Published by the BMJ Publishing Group Limited. For permission to use (where not already granted under a licence) please go to http://group.bmj.com/group/rights-licensing/ permissionsThis is an Open Access article distributed under the terms of the Creative Commons Attribution IGO License (https://creativecommons.org/licenses/by-nc/3.0/igo/), which permits use, distribution, and reproduction for non-commercial purposes in any medium, provided the original work is properly cited. 